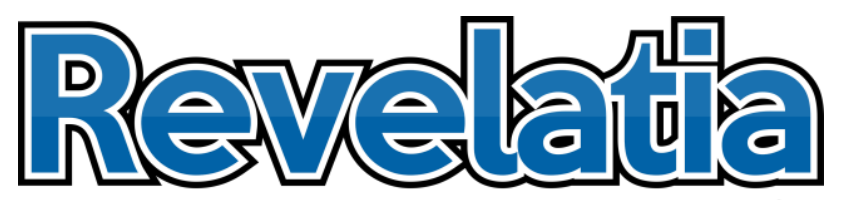

Jurnal Ilmu Al-Qur'an and Tafsir

P-ISSN: 2721-5962 I E-ISSN: 2721-768X

\title{
Cadar dan Resepsi Al-Quran pada Mahasiswi IAIN Madura: Analisis pada Surah Al-Ahzab (33) Ayat 59 dan Al-Nur (24) Ayat 31 dalam Kitab Tafsir Al-Azhar
}

\author{
Risalatil Falihah \\ (Guru TPQ PAUD H.I. El-Fath Sumenep, \\ e-mail: arisyfa7putri@gmail.com)
}

\begin{abstract}
:
Niqab which was known by Arabs before Islam currrently became a dress choice for other Muslimah. Use of niqab among female students at IAIN Madura increased year by year. Thus, the reason related to its use was a question of this paper. This study employed qualitative method with descriptive phenomenological approach. While the data were collected by using observation, interview and documentation technique. Some informants involved were female students whose wear niqab, lecturers and other students. Triangulation was used as data validation method. This study found that some reasons of wearing niqab among female students are the belief of self-dignity, self-guide, and the feel of self-peaceful. On the other hand, female students with niqab encountered stereotypical experiences such as judged as terrorist and being discriminated by their family and surroundings.
\end{abstract}

\begin{abstract}
Abstrak:
Cadar merupakan model pakaian dan perhiasan wanita yang sudah dikenal oleh sebagian bangsa Arab sebelum Islam. Fenomena cadar yang ada di IAIN Madura setiap tahunnya semakin banyak. Namun motivasi pemakaiannya belum diketahui dengan pasti. Artikel ini bersumber dari penelitian yang dilakukan dengan menggunakan jenis penelitian kualitatif dan menggunakan pendekatan fenomenologis deskriptif. Adapun teknik pengumpulan data yang dilakukan adalah dengan cara observasi, wawancara dan dokumentasi. Informan yang terlibat diantaranya, sebagian mahasiswi bercadar, dosen dan mahasiswa. Sedangkan pengecekan keabsahan data melalui ketekunan pengamatan dan triangulasi. Hasil dari artikel ini ialah: cadar merupakan kain penutup wajah yang dipakai oleh sebagian muslimat untuk menjaga kehormatan dirinya. Motivasi mahasiswi IAIN Madura memakai cadar ialah untuk menjaga diri dari hal-hal yang kurang baik, baik yang dilakukan oleh orang lain atau oleh diri sendiri serta dapat memberikan rasa aman dan tenang terhadap pemakainya. Problematika yang dialami oleh mahasiswi bercadar ialah dengan dikaitkannya dirinya dengan teroris, tidak bisa diterima dengan
\end{abstract}




\section{Risalatil Falihah}

baik oleh keluarga, teman, atau lembaganya atau diperlakukan dengan tidak senonoh. Solusi yang dilakukan oleh mahasiswi bercadar IAIN Madura atas setiap problem yang dihadapinya ialah dengan cara diam, bersabar dan membicarakannya dengan baik-baik.

Kata Kunci: Cadar; Mahasiswi; Tafsir al-Azhar

\section{PENDAHULUAN}

Agama merupakan pedoman hidup manusia dalam setiap permasalahan yang dihadapi, sehingga tercipta kedamaian lahir dan batin. Agama juga menjadi tolak ukur di setiap pergaulan antar umat, pemahaman antara yang baik dan yang buruk, pemahaman antara yang benar dan yang salah dan juga antara yang boleh dan tidak boleh dilakukan karena ajaran agama menentukan konsep kepercayaan dengan berpedoman pada sumber hukum utamanya yaitu al-Qur'an. Setiap umat beragama wajib mempelajari dan mentaati ajaran agamanya, baik dari segi perintah ataupun larangan. Seperti agama Islam yang mengharuskan bahkan mewajibkan bagi umatnya untuk mempelajarinya serta menerima setiap interpretasi dari hal-hal yang sudah dipelajari. ${ }^{1}$

Al-Qur'an merupakan satu-satunya kitab suci yang menjadi pedoman bagi umat Islam. Al-Qur'an bukan hanya dipergunakan untuk dibaca, melainkan juga untuk dipelajari dan dipahami, baik dari segi lafal, makna, ragam bacaan maupun cara membacanya. Oleh karena itu lahirlah beberapa ilmu yang berkaitan dengan hal tersebut seperti ilmu terjemah al-Qur'an, ilmu tafsir al-Qur'an, ilmu qiraah dan ilmu tajwid.2 Karena meluasnya ilmu-ilmu tersebut, banyak umat muslim yang ingin mempelajari dan memahami al-Qur'an serta banyak pula para pemaham al-Qur'an yang berusaha menjadi insan qur'ânī dengan cara melakukan atau mematuhi setiap perintah yang ada di dalam al-Qur'an.

Terdapat salah satu kisah dalam al-Qur'an, yaitu kisah Nabi Syu'aib dan Nabi Musa yang melarang perempuan keluar rumah dan menjelaskan hakikat tugas perempuan yaitu memberikan kedamaian kepada suaminya, mengasuh putra-putrinya, dan mendidik dengan pendidikan Islami secara benar. Tampak dari kisah tersebut dapat diketahui bahwa tugas perempuan adalah di dalam rumah, bukan keluar rumah, atau bahkan bertemu dan berdesakan dengan laki-laki. Namun perempuan juga diperbolehkan keluar rumah dikarenakan ada sesuatu yang sangat urgen baginya. Larangan keluar rumah bagi perempuan merupakan salah satu dari bentuk penghormatan dan perlindungan al-Qur'an kepada kaum perempuan. Mutawalli al-

\footnotetext{
${ }^{1}$ Indra Tanra, "Persepsi Masyarakat Tentang Perempuan Bercadar", Jurnal Equilibrium, Vol. III, No. 1, (Mei, 2015), 116.

${ }^{2}$ Idham Hamid, "Tradisi Membaca Yasin di Makam Annangguru Maddappungan Santri Pondok Pesantren Salafiyah Parappe Kec. Campalagian Kab. Polewali Mandar" (Skripsi, Universitas Islam Alamuddin, Makassar, 1994), 1.
} 
Sya'râwī (w. 1911 H) mengatakan bahwa Allah swt. memberikan syarat kepada kaum perempuan sebelum keluar rumah yaitu: Pertama, tidak bercampur dan berdesakan dengan laki-laki. Kedua, tidak berdandan berlebihan karena hal tersebut dapat membahayakan perempuan tersebut. ${ }^{3}$

Terdapat beberapa perubahan pesat yang terjadi dalam kehidupan, salah satunya adalah gaya berpakaian. Hampir setiap hari ditemui pembaharuan model pakaian, khususnya pada wanita, yang bisa diketahui baik dari layar kaca, media sosial, ataupun majalah. Agama Islam sebagai agama yang dominan di Indonesia sebenarnya sudah mengatur cara berpakaian wanita. Beberapa ayat dalam al-Qur'an ditafsirkan oleh beberapa mufassir sebagai petunjuk atau cara berpakaian bagi wanita yang benar dan aman, salah satunya disebutkan dalam surah al-Nur (33) ayat 31 yang berbunyi;

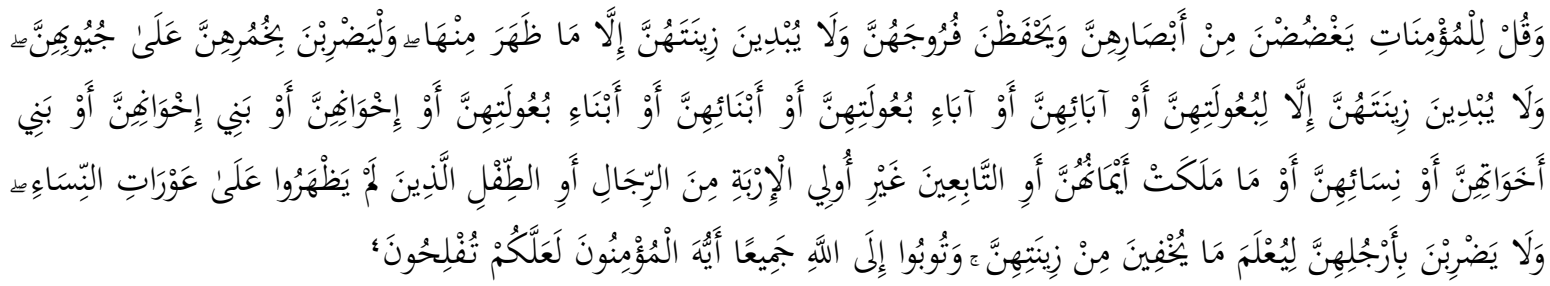

“Katakanlah kepada wanita yang beriman: "Hendaklah mereka menahan pandangannya, dan kemaluannya, dan janganlah mereka menampakkan perhiasannya, kecuali yang (biasa) nampak dari padanya. Dan hendaklah mereka menutupkan kain kudung ke dadanya, dan janganlah menampakkan perhiasannya kecuali kepada suami mereka, atau ayah mereka, atau ayah suami mereka, atau putera-putera mereka, atau putera-putera suami mereka, atau saudara-saudara lakilaki mereka, atau putera-putera saudara lelaki mereka, atau putera-putera saudara perempuan mereka, atau wanita-wanita islam, atau budak-budak yang mereka miliki, atau pelayan-pelayan laki-laki yang tidak mempunyai keinginan (terhadap wanita) atau anak-anak yang belum mengerti tentang aurat wanita. Dan janganlah mereka memukulkan kakinyua agar diketahui perhiasan yang mereka sembunyikan. Dan bertaubatlah kamu sekalian kepada Allah, hai orang-orang yang beriman supaya kamu beruntung."

Bagi masyarakat Indonesia khususnya yang beragama muslim, yang dimaksud dengan menutup aurat ialah memakai kerudung atau jilbab yang mana hal tersebut sudah tercantum dalam kitab tafsir al-Azhar. Perintah memakai jilbab juga sudah dengan jelas disebutkan di dalam Al-Qur'an Surah al-Ahzab (24): 59 yang berbunyi;

\footnotetext{
3 Mutawalli al-Sya'râwī, Fikih Perempuan (Muslimah) Busana dan Perhiasan, Penghormatan atas Perempuan, Sampai Wanita Karier (Jakarta: Amzah, 2003), 149.

${ }^{4}$ Al-Qur'an, Al-Nur (24): 31.
}

REVELATIA: Jurnal Ilmu Al-Qur'an dan Tafsir 


\section{Risalatil Falihah}

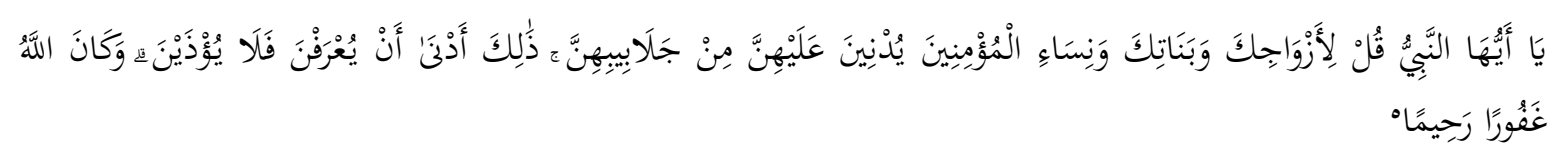

“Hai Nabi, katakanlah kepada isteri-isterimu, anak-anak perempuanmu dan isteriisteri orang mukmin: "Hendaklah mereka mengulurkan jilbabnya ke seluruh tubuh mereka". Yang demikian itu supaya mereka lebih mudah untuk dikenal, karena itu mereka tidak di ganggu. Dan Allah adalah Maha Pengampun lagi Maha Penyayang."

Kedua ayat tersebut merupakan perintah kepada semua kaum wanita di manapun tempat tinggalnya untuk tetap menutup auratnya. Alasan logis wanita diperintah untuk menutup aurat di hadapan orang lain ialah untuk melindungi wanita tersebut dari gangguan laki-laki usil, menjadi indikator keluhuran budi pekerti seorang wanita, mencegah timbulnya fitnah birahi laki-laki, serta menjaga kesucian wanita. ${ }^{6}$

Fitrah yang dimiliki oleh setiap manusia, baik laki-laki maupun perempuan ialah rasa ketertarikan satu sama lain atau hawa nafsu. Mutawalli al-Sya'râwī (1911) mengatakan dalam bukunya bahwa perasaan manusia dibagi menjadi tiga, yaitu al-idrâk (penglihatan), al-wijdân (emosi), dan an-nuz $\hat{u}^{\prime}$ (keinginan). Ajaran agama tidak menyoroti pada semua bagian tersebut, tetapi hanya menfokuskan pada satu sisi saja, yaitu an-nuz $\hat{u}^{\prime}$ (keinginan). Sya'râwī mengibaratkan pada seseorang yang melihat bunga yang indah di taman. Ketika orang tersebut tertumpu pada penglihatan tersebut, maka hal itu merupakan bagian dari al-idrâk (penglihatan). Apabila seseorang tersebut terkesan tertarik pada bentuk bunga tersebut yang indah, maka hal tersebut merupakan bagian dari alwijdân (emosi). Apabila emosi tersebut cukup mempengaruhi dirinya sehingga ada keinginan untuk memetiknya, itulah yang disebut dengan an-nuz $\hat{u}^{\prime}$ (keinginan). ${ }^{7}$

Salah satu bentuk penghormatan Al-Qur'an terhadap wanita ialah diwajibkannya memakai jilbab. Kerena dengan demikian, para wanita menjadi aman dari pandangan laki-laki yang bukan muhrimnya. Jilbab selain merupakan bentuk nyata dari penghormatan Al-Qur'an terhadap kaum perempuan juga berfungsi untuk menutup aurat atau anggota tubuh wanita yang dianggap rawan serta dapat menimbulka fitnah. Berbagai cara atau gaya yang dilakukan oleh para wanita dalam menutup auratnya diantaranya dengan memakai kain penutup kepala (selendang), memakai himar, hijab, jilbab, cadar, sampai burkah, tergantung pada pemahaman mereka masing-masing tentang menutup aurat.

Cadar pertama kali diperkenalkan oleh agama Yahudi dan Kristen, dua agama besar sebelum adanya agama Islam, dan diwajibkan penggunaannya bagi kaum perempuan. Dengan kata lain, cadar sudah ada sebelum Islam dan sebelum ayat-ayat

\footnotetext{
${ }^{5}$ Al-Qur'an, Al-Ahzab (33): 59.

${ }^{6}$ Ade Susanti, “Gambaran Persahabatan dan Penysuaian Diri pada Mahasiswi UIN Jakarta yang Mengenakan Cadar (Skripsi, Universitas Islam Negeri Syarif Hidayatullah, Jakarta, 2008),, xv.

7 al-Sya'râwī, Fikih Perempuan (Muslimah) Busana, 149.
} 
tentang jilbab diturunkan. Cadar merupakan model pakaian dan perhiasan wanita yang sudah dikenal oleh sebagian bangsa Arab sebelum Islam turun. ${ }^{8}$ Sedangkan di Indonesia, cadar dikenal melalui beberapa ulama Indonesia yang menuntut ilmu ke tanah suci Mekah dan kemudian pulang dengan mensosialisasikan pemakaian cadar kepada para wanita Indonesia. Kesadaran menutup aurat sendiri bagi wanita Indonesia khususnya di daerah Sunda sudah dikenal sejak sekitar tahun 1870-an dengan bentuk pemakaian mukenah pada saat salat dan pemakaian jilbab di kehidupan sehari-hari. ${ }^{9}$

Terdapat beberapa perbedaan pendapat para mufassir mengenai kewajiban memakai cadar. Perbedaan tersebut sudah tidak bisa dicegah karena sudah berdasarkan pada argumen atau landasan yang kuat dari masing-masing mufassir. Di antaranya ialah pendapat Wahbah al-Zuhailī (w. 1932) yang mewajibkan terhadap pemakaian cadar karena menganggap bahwa wajah termasuk pada aurat yang wajib ditutupi. ${ }^{10}$ Sama halnya dengan pendapat al-Zuhailī, Jalâl al-Dīn Muhammad bin Ahmad al-Mahallī Syaikh al-Mutabahhar (w. 1389) dan Jalâl al-Dīn 'Abdu ar-Rahman bin Abī Bakrin asSuyûthī (w. 1445) dalam tafsirnya yaitu Tafsīr al-Qur'an al-'Azhīm yang juga mewajibkan pemakaian cadar apabila dikhawatirkan akan menimbulkan fitnah dan tidak wajib apabila tidak dikhawatirkan akan timbul fitnah. ${ }^{11}$ Sedangkan menurut al-Marâghī (w. 1883), sependapat dengan beberapa pendapat mufasir Nusantara yaitu Buya Hamka (w. 1908) dan Quraish Shihab tidak mewajibkan pemakaian cadar dengan alasan wajah tidak termasuk aurat. ${ }^{12}$

Perbedaan penggunaan jilbab dengan cadar hanya pada atributnya saja. Jilbab merupakan penggunaan baju panjang yang menutup aurat bukan hanya di kepala saja, tetapi juga di seluruh tubuh sampai kedua kaki, kecuali wajah dan telapak tangan. Aurat merupakan bagian anggota tubuh yang harus ditutupi atau tidak boleh diperlihatkan secara umum kepada lawan jenis yang bukan muhrim ${ }^{13}$ nya. Sedangkan cadar pemakaiannya diikuti dengan gamis dan rok-rok panjang dan lebar yang biasanya berwarna hitam atau gelap. Cadar merupakan pakaian lanjutan dari jilbab. Penggunaan cadar hanya menambah aksesoris penutup pada wajah sehingga hanya terlihat mata saja. Selain dari aksesoris, penggunaan cadar juga biasanya identik dengan pengaturan

\footnotetext{
${ }^{8}$ Romadhoni Kusnul Khotimah, "Komunikasi Perempuan Bercadar di Komunitas Kahf Surabaya" (Skripsi, Universitas Islam Negeri Sunan Ampel, Surabaya, 2018), 42.

${ }^{9}$ Khairunnisa Y, "Komunikasi Nonverbal Muslimah Bercadar di Kalangan Mahasiswi UIN arRaniry" (Skripsi, Universitas Islam Negeri ar-Raniry, Banda Aceh, 2017), 42.

${ }^{10}$ Wahbah az-Zuhailī, al-Tafsir al-Munîr fi al-'aqî̉ah wa asy-syarî́ah wa al-Manhaj (Beirut: Dâr al-Fikr, 2011), vol. 11, 430.

${ }^{11}$ Jalâl al-Dīn Muhammad bin Ahmad al-Mahallī Syaikh al-Mutabahhar dan Jalâl al-Dīn 'Abdu arRahman bin Abī Bakrin as-Suyûthī, Tafsìr al-Qur'an al-'Azhīm (Surabaya: Dâr al-Jawâhir, t.t), 112.

${ }^{12}$ Ahmad Mushthafa al-Marâghī, Tafsir al-Marâghī (Beirut: Dâr al-Fikr, 2010), 23.

${ }^{13}$ Muhrim adalah lawan jenis yang diharamkan untuk dinikahinya karena ada hubungan keluarga. Alif Fathur Rahman dan Muhammad Syafiq, "Motivasi, Stigma dan Coping Stigma pada Perempuan Bercadar", Jurnal Psikologi Teori dan Terapan, Vol. 7, No. 2, (Februari, 2017), 104.
} 


\section{Risalatil Falihah}

pembatasan sikap dalam interaksi dengan lawan jenis terutama yang bukan muhrimnya untuk lebih menjaga diri dari fitnah dan dosa. ${ }^{14}$

Kata Living Qur'an mulanya berasal dari kata Qur'an in Everyday Life, yaitu makna dan fungsi Al-Qur'an yang riil dipahami dan juga dialami masyarakat muslim. Arti penting dari kajian Living Qur'an ialah memberikan pandangan baru terhadap kajian AlQur'an kontemporer sehingga kajian studi al-Qur'an tidak hanya berkutat pada wilayah kajian teks saja. Living Qur'an merupakan suatu fenomena sosial yang masih berpusat atau berpangkal pada al-Qur' an seperti fenomena pembacaan al-Qur'an di lokasi tertentu, fenomena penulisan bagian-bagian tertentu dari al-Qur'an di tempat tertentu, fenomena pemenggalan unit-unit al-Qur'an yang kemudian menjadi formula pengobatan, fenomena pengusiran jin yang merasuk pada tubuh manusia dengan menggunakan ayat-ayat teryentu, juga fenomena praktik dari makna-makna al-Qur'an yang dilakukan masyarakat dalam kesehariannya seperti cara bersosial atau berpakaian yang salah satunya seperti fenomena memakai cadar dalam masyarakat. ${ }^{15}$

Tafsir al-Azhar merupakan kitab Tafsir karya ulama Nusantara yang cukup familiar di Indonesia yaitu Buya Hamka. Kitab Tafsir yang menggunakan metode tahlili tersebut merupakan kitab tafsir 30 juz yang terdiri dari 9 jilid. Penulisan kitab Tafsir ini dimulai dari penafsiran surah al-Kahfi juz 17 dan pertama kali disampaikan pada jamaah masjid al-Azhar setelah salat subuh berjamaah. Hamka menulis kitab Tafsirnya dalam waktu 20 tahun dan penyelesaiannya dilakukan dipenjara. Kitab tafsir tersebut merupakan pencapaian dan sumbangan terbesarnya dalam membangun pemikiran dan mengangkat tradisi ilmu sehingga melahirkan sejarah penting dalam penulisan tafsir Nusantara. ${ }^{16}$

Bagi masyarakat Indonesia yang sebagian besar penduduknya beragama Islam, cadar bukan menjadi hal yang baru. Sehingga tak jarang dijumpai wanita bercadar dalam kehidupan dan aktifitas sehari-hari. Terlepas dari pandangan positif masyarakat tentang cadar, banyak juga masyarakat yang menilai negatif terhadap wanita bercadar dengan sering menggapnya sebagai kelompok fanatik dan jaringan terorisme. Beberapa kendala yang dialami oleh wanita bercadar ialah penolakan oleh keluarga ataupun lembaganya. Hal tersebut dikarenakan adanya dugaan cadar merupakan pakaian yang identik dengan ekstrimisme. ${ }^{17}$ Pemakaian cadar juga dianggap sebagai sikap fanatisme terhadap agama dan tidak jarang wanita bercadar dianggap golongan radikal. Salah satu alasan masyarakat memandang sebelah mata pada wanita bercadar dikarenakan beberapa stigma yang dikeluarkan oleh media yang mengatakan wanita bercadar sebagai 'istri

\footnotetext{
${ }^{14}$ Ibid, 104.

${ }^{15}$ M. Mansur, Metodologi Penelitian Living Qur'an dan Hadis (Yogyakarta: Teras, 2007), 8.

${ }^{16}$ Avif Alviyah, "Metode Penafsiran Buya Hamka dalam Tafsir al-Azhar", Ilmu Ushuluddin, Vol.15, No. 1, (Januari 2016), 29.

${ }^{17}$ Maya Setyarini, "Prasangka Sosial Civitas Akademika Terhadap Wanita Bercadar di Lingkungan Perguruan Tinggi Islam" (Skripsi, Universitas Muhammadiyah, Surakarta, 2018), 2.
} 
teroris', 'Islam garis keras', dan ketertutupan wanita bercadar dapat menghambat komunikasi dan proses sosialisasi. Tidak semua wanita menerima terhadap keberadaan wanita bercadar. Sebagian golongan yang tidak menerima wanita bercadar dengan alasan masing-masing. Sebagian yang lain mengatakan pemakaian cadar hanya menyulitkan pemakainya dan penggunaan cadar harus disesuaikan dengan lingkungannya, sedangkan di lingkungan Indonesia tidak diwajibkan bercadar. ${ }^{18}$

Cadar marak dikenakan bukan hanya di kalangan masyarakat terbuka saja, melainkan juga di kalangan terterntu seperti di kalangan akademisi. Salah satu contohnya fenomena yang terjadi pada mahasiswi di Perguruan Tinggi IAIN Madura, Pamekasan. Beberapa tahun terakhir sudah mulai banyak ditemukan mahasiswi yang memakai cadar, mulai dari yang hanya memakai masker sampai ke cadar atau niqâb..$^{19}$ Dari data yang sudah terkumpul, dalam tahun ademik 2018-2019 tercatat 27 mahasiswi yang memakai cadar di IAIN Madura, dengan rician; 4 mahasiswi dari Fakultas Ushuludin dan Dakwah, 2 mahasiswi dari Fakultas Syariah, 4 mahasiswi dari Fakultas Ekonomi dan Bisnis Islam, dan 17 mahasiswi dari Fakultas Tarbiyah. Data tersebut diperoleh dengan cara menanyakan kepada salah satu mahasiswa perwakilan dari setiap kelas yang biasanya hal tersebut disebut dengan observasi awal. Untuk mendapatkan data yang akurat penulis melakukan semua pencarian data dengan dirinya sendiri.

Madura yang merupakan masyarakat religius terbuka tidak mungkin jika mekatakan cadar sebagai pakaian atau identitas aslinya. Religiusitas masyarakat Madura sudah dikenal luas sebagai bagian dari keberagaman kaum muslim Indonesia yang berpegang teguh pada ajaran Islam dalam menapak realitas kehidupan soaial budayanya. Namun, dahulu jarang sekali ditemukan masyarakat bercadar di pulau Madura. Sudah diketahui bersama bahwa cadar berasal dari budaya di luar Madura yang dari dulu memang sudah digunakan untuk menutupi wajah, minimal untuk menutupi hidung dan mulut. Lalu budaya tersebut dikenal oleh berbagai kalangan di berbagai daerah atau negeri. Karena pengetahuan tentang cadar yang sudah tersebar membuat cadar juga cukup banyak diminati oleh berbagai kalangan, salah satunya oleh kalangan muslimah di Indonesia, termasuk juga beberapa mahasiswi di IAIN Madura. Pengetahuan mereka terhadap cadar pun juga bermacam-macam. Latar belakang mereka memakai cadar pun juga belum diketahui secara pasti, apakah karena mereka termasuk para pemahaman figh $\hat{\imath}$ (ijma' dan qiyâs), atau para pemaham syarî'at (Al-Qur'an dan hadis), atau karena pemaham keduanya, atau sudah tradisi atau kebiasan di keluarganya.

Maka dari itu, peneliti ingin menelusuri lebih jauh tentang motivasi mahasiswi dalam menggunakan cadar yang kemudian akan dilihat kesesuaiannya dengan makna

\footnotetext{
${ }^{18}$ Mei Rusmiyati, "Perilaku Komunitas Mahasiswi S1 yang Bercadar di IAIN Purwokerto" (Skripsi, IAIN Purwokerto, Purwokerto, 2017), 1.

${ }_{19}$ Niqâb adalah istilah syar'î untuk kata cadar yaitu dalam Islam merupakan jilbab tebal dan longgar yang menutupi seluruh anggota tubuh termasuk wajah dan telapak tangan. Setyarini, Prasangka Sosial Civitas Akademika Terhadap Wanita Bercadar di Lingkungan Perguruan Tinggi Islam, 2.
} 


\section{Risalatil Falihah}

yang tersurat dalam Alqur'an surah al-Ahzab (33) ayat 59 dan al-Nur (24) ayat 51 dalam Tafsir al-Azhar, dengan judul penelitian "Fenomena Cadar Mahasiswi IAIN Madura (Kajian Surat Al-Ahzab (33) Ayat 59 dan Al-Nur (24) Ayat 31) dalam Tafsir al-Azhar".

\section{METODE PENELITIAN}

Metode penelitian adalah cara yang sistematis serta logis yang digunakan dalam sebuah riset untuk mencapai tujuan riset tertentu. ${ }^{20}$ Metode yang digunakan dalam penelitian ini adalah field research (penelitian lapangan). Dengan menggunakan metode penelitian tersebut peneliti berusaha mencari sumber data yang diperlukan di lapangan yaitu dengan observasi dan wawancara. Metode tafsir yang cocok pada penelitian tafsir yang penulis lakukan ialah metode Living Qur'an, yaitu dengan meneliti fenomena yang ada pada masyarakat yang merupakan salah satu praktik dari perintah al-Qur'an yaitu memakai cadar. Pendekatan yang digunakan dalam penelitian ini adalah pendekatan fenomenologis yaitu memaparkan fenomena yang terjadi di lapangan dengan menceritakan kembali melalui data yang diperoleh. ${ }^{21}$ Kemudian jenis penelitian yang peneliti pilih ialah penelitian kualitatif dengan memaparkan data secara deskriptif. ${ }^{22}$ Kehadiran peneliti di lapangan sangat penting dalam penelitian kualitatif, karena peneliti bertindak sebagai instrument utama atau key instrument serta pengumpul data dalam memperoleh data yang diperlukan oleh peneliti, sehingga kehadiran peneliti di lapangan dirasa penting dalam memperoleh informasi yang dibutuhkan oleh peneliti untuk mencapai tujuan penelitian. ${ }^{23}$ Lokasi penelitian terletak di Institut Agama Islam Negeri Madura (IAIN Madura) karena pada perguruan tinggi ini selama beberapa tahun terakhir mulai ditemui beberapa mahasiswi yang menggunakan cadar.

Dalam penelitian ini, data yang akan diperoleh berupa deskriptif, kata-kata, tindakan, serta dokumentasi dan lain sebagainya. Kemudian sumber datanya bersumber dari manusia dan non-manusia. Sumber data yang bersumber dari manusia adalah beberapa mahasiswi IAIN Madura yang memakai cadar, dosen dan mahasiswi. Adapun data yang diperoleh dirumuskan dalam bentuk wawancara dan pengamatan lapangan (observasi). Sedangkan data yang bersumber dari non-manusia adalah beberapa dokumentasi yang diambil pada saat pelaksanaan wawancara (interview). ${ }^{24}$ Prosedur pengumpulan data yang dilakukan dalam penelitian ini adalah dengan cara observasi, wawancara dan dokumentasi. Obsevasi yang dilakukan dalam penelitian ini ialah observasi non-partisipan yaitu pengamatan dengan tanpa memposisikan diri sebagai

\footnotetext{
${ }^{20}$ Abdul Mustaqim, Metode Penelitian al-Qur'an dan Tafsir (Yogyakarta: Idea Press Yogyakarta, 2015), 2.

${ }^{21}$ Lexy J. Moleong, Metodologi Penelitian Kualitatif (Bandung: PT Remaja Rosdakarya, 2016), 4.

22 Ibid, 6.

${ }^{23}$ Andi Prastowo, Metode Penelitian Kualitatif dalam Perspektif Rancangan Penelitian (Jogjakarta: ArRuzz Media, 2012), 32.

${ }^{24}$ Prastowo, Metode Penelitian Kualitatif dalam Perspektif Rancangan Penelitian, 43.
} 
bagian dari kelompok yang diteliti dikarenakan observasi dengan model tersebut sudah penulis rasa cukup efektif dalam penelitian meskipun tanpa memposisikan peneliti pada objek yang akan diteliti. ${ }^{25}$ Jenis wawancara yang digunakan dalam penelitian ini adalah wawancara semi terstruktur (semistructure interview) yang merupakan gabungan antara wawancara terstruktur dan tidak terstruktur. Karena dengan wawancara semi terstruktur peneliti bisa menemukan permasalahan secara lebih terbuka dimana pihak yang diajak wawancara diminta pendapat dan ide-idenya. Dalam melakukan wawancara, peneliti perlu menyimak secara teliti dan mencatat da juga merekam apa yang dikemukakan oleh informan. ${ }^{26}$ Dokumentasi ialah teknik pengumpulan data dan informasi melalui pencarian dan penemuan bukti-bukti dalam arti metode pengumpulan data yang berasal dari sumber nonmanusia. ${ }^{27}$ Dokumen-dokumen yang dikumpulkan akan membantu peneliti dalam memahami fenomena yang terjadi di lokasi penelitian juga membantu dalam membuat interpretasi data, serta dalam menyusun teori dan melakukan validitas data.

Selanjutnya adalah analisis data. Analisis data adalah kegiatan yang dilakukan oleh peneliti untuk mengklasifikasi data sehingga peneliti dapat memperoleh kesimpulan. Analisis data dilakukan saat proses pencarian data dan sesudahnya. Adapun tahap-tahapnya adalah;

Reduksi Data

Reduksi data berarti merangkum, memilih hal-hal yang pokok, memfokuskan pada hal-hal yang penting, mencari tema dan polanya. ${ }^{28}$ Adapun tahap-tahap reduksi data adalah sebagai berikut:

Pengecekan Data (Checking)

Pengecekan data dapat dilakukan dari hasil wawancara, observasi dan hasil dokumentasi yang diperoleh.

\section{Pengelompokan Data (Organizing)}

Pengorganisasian dilakukan untuk mengelompokkan data yang diperoleh dari lapangan sesuai dengan fokus yang sudah ditentukan.

Display Data/Penyajian Data

Dalam penelitian kualitatif penyajian data dapat dilakukan dalam bentuk uraian singkat, bagan, hubungan antar kategori dan sejenisnya. ${ }^{29}$ Display data yang digunakan dalam penelitian ini ialah berbentuk teks yang bersifat naratif.

\footnotetext{
${ }^{25}$ Nastution, Metode Research: Penelitian Ilmiah (Jakarta: Bumi Aksara, 2012), 107.

${ }^{26}$ Haris Herdiansyah, Wawancara, Observasi, dan Focus Groups Sebagai Instrumen Penggalian Data Kualitatif (Jakarta: Rajawali Pers, 2015), 63.

27 Ibid, 141.

${ }^{28}$ Afifuddin \& Saebani, Metodologi Penelitian, 184.

${ }^{29}$ Ibid, 184.
} 


\section{Risalatil Falihah}

Kesimpulan/verifikasi

Kegiatan analisis yang penting adalah menarik kesimpulan dan verifikasi. Kesimpulan dalam penelitian kualitatif ada kemungkinan dapat menjawab fokus penelitian yang sudah ditentukan sejak awal, tetapi bisa juga tidak, karena fenomena dan fokus penelitian dalam penelitian kualitatif masih bersifat sementara dan akan berkembang setelah peneliti berada di lapangan. Idealnya penarikan kesimpulan harus didasarkan atas data, bukan atas angan-angan atau keinginan peneliti. ${ }^{30}$

Maka dengan demikian pengambilan kesimpulan dilakukan setelah peneliti yakin bahwa data yang diperoleh dalam penelitian adalah benar. Sedangkan verifikasi merupakan pengecekan ulang yang dilakukan untuk meyakinkan bahwa data yang diperoleh adalah benar.

Kemudian Pengecekan Keabsahan Data. Untuk mengetahui apakah data yang diperoleh dalam penelitian ini valid, maka peneliti perlu mengadakan teknik pengecekan keabsahan data. Pelaksanaan teknik pemeriksaan didasarkan atas sejumlah kriteria tertentu. Keabsahan data dapat dilihat dari kredibilitas dan juga dari kepastiannya, di mana kredibilitas dapat dilakukan dengan cara berikut:

Ketekunan Pengamatan

Ketekunan pengamatan bermaksud untuk mengadakan pengamatan dengan lebih teliti dan rinci secara berkesinambungan dalam memahami suatu gejala, peneliti juga dapat menetapkan mana aspek yang penting dan yang tidak dalam pengumpulan data serta dapat memusatkan perhatian kepada aspek yang relevan dengan topik. ${ }^{31}$

\section{Ketekunan Pengamatan}

Triangulasi adalah teknik pemeriksaan data yang memanfaatkan sesuatu yang lain. ${ }^{32}$ Dapat pula dikatakan sebagai pemeriksaan validitas temuan yang memanfaatkan sesuatu yang lain diluar data ini dengan tujuan untuk keperluan pengecekan atau membandingkan data yang ada di lapangan. Triangulasi ini dapat ditempuh melalui sumber, metode, dan teori.

Sedangkan pengecekan keabsahan data dengan kepastian dapat dilakukan dengan teknik uraian rinci dari data yang telah diperoleh untuk dipaparkan, kemudian dianalisis untuk menghindari ketidaksesuaian sehingga menunjukkan kebenaran sebagaimana mestinya.

\section{HASIL DAN PEMBAHASAN}

Pengertian cadar menurut informan ialah kain yang berfungsi menutupi wajah sehingga hanya terlihat mata saja. Pernyataan tersebut sesuai dengan teori yaitu, cadar

\footnotetext{
${ }^{30}$ Arikunto, Prosedur Penelitian suatu Pendekatan Praktik, 385

${ }^{31} \mathrm{Ibid}, 329-330$.

32 Ibid, 330.
} 
merupakan kain penutup wajah bagi wanita yang menutupi mulut dan hidung sehingga hanya terlihat mata saja. Istilah Arab dari cadar adalah niqâb. Dinamakan niqâb (penutup wajah) karena masih ada lubang pada daerah mata yang dipergunakan untuk melihat jalan dan sekitar. Cadar oleh para ulama juga sering disebut dengan "hijab". Dalam makna harfiyah, "hijab" memiliki arti "pemisah pergaulan antara laki-laki dan perempuan". 33

Terdapat beberapa motivasi atau alasan mahasiswi IAIN Madura menggunakan cadar di antaranya yaitu karena ingin menjadi wanita shalihah, memperbaiki diri dan menghilangkan masa lalu yang kurang baik, ingin lebih menjaga diri, dan karena termotivasi dari orang lain. Berkaitan dengan hal tersebut, telah diketahui bahwasanya terdapat dua motivasi yang mendorong wanita menggunakan cadar yaitu karena motivasi internal dan motivasi eksternal. Motivasi internalnya ialah karena untuk menjaga kehormatan diri sebagai seorang muslimah dan harapan untuk menjadi wanita salihah serta berusaha mengubur masalalu kelam yang pernah dialaminya. Sedangkan faktor eksternal dari pemakaian cadar ialah karena adanya sosok tokoh atau seseorang yang diteladaninya karena ada rasa kagum atau karena merasa ketularan aura positif saat bersama dengan wanita bercadar. Alasan selanjutnya dari faktor internal ini karena adanya kewajiban atau kebijakan dari sekolah atau lembaga yang ditempuh olehnya. ${ }^{34}$

Tidak semua dosen IAIN Madura setuju terhadap mahasiswi IAIN Madura yang memakai cadar dikarenakan menurutnya lingkungan yang tidak tepat untuk menggunakan cadar. Namun sebagian dosen juga menyetujui dengan pemakaian atribut cadar yang digunakan mahasiswi IAIN Madura karena dosen tersebut mengerti akan pemahaman mahasiswi tentang agama dan hal tersebut juga dapat mencegah terjadinya fitnah yang mungkin akan tersebar. Namun pada pembahasan tersebut belum ditemukan teori yang cocok dengan temuan lapangan yang dibahas di atas dan menjadi temuan baru yang peneliti temukan dilapangan.

Begitu pula dengan mahasiswa/i yang ada di IAIN Madura yang tidak seluruhnya menerima atribut cadar dipakai mahasiswi dikarenakan pemakaian di area kampus terkesan terlalu ekstrim dan seperti hujatan terhadap mahasiswa bahwa dirinya itu kotor dan bermasalah. Namun sebagian lagi menerima atau setuju karena hal tersebut merupakan suatu hal yang baik dan dapat membawa kebaikan bagi orang lain. Pembahasan tentang hal ini juga belum peneliti temukan teori yang cocok dikaitkan dengan temuan lapangan ini dan menjadi temuan yang peneliti temukan di lapangan.

Kelebihan yang dimiliki oleh cadar baik menurut pihak yang bercadar ataupun pihak yang tidak bercadar di IAIN Madura ialah merasa lebih terlindungi dan terjaga, tidak banyak pengeluaran buat membeli make up, bisa lebih dihargai dan dihormati, bisa

\footnotetext{
${ }_{33}$ Susanti, "Gambaran Persahabatan dan Penysuaian Diri pada Mahasiswi UIN Jakarta yang Mengenakan Cadar", vii.

34 Alif Fathur Rahman dan Muhammad Syafiq, "Motivasi, Stigma dan Coping Stigma pada Perempuan Bercadar", 106
} 


\section{Risalatil Falihah}

memberikan dampak positif terhadap orang lain, dan dapat menghindari diri dari fitnah. Temuan tersebut juga merupakan temuan baru yang peneliti temui di lapangan karena tidak ada teori atau pembahasan yang juga membahas tentang hal tersebut. Sedangkan kekurangan dari cadar ialah seseorang yang belum terbiasa akan sedikit sulit untuk makan di luar rumah, merasa berdosa kepada Allah, diri sendiri dan orang lain, lebih terbatas, dapat menimbulkan prasangka yang kurang baik, terlihat rumit dan membatasi transaksi muamalah, dan sulit diketahui identitasnya. Paparan tersebut juga merupakan temuan bar yang peneliti temui di lapangan karena tidak peneliti temukan teori yang cocok membahas hal tersebut.

Selain di masyarakat, di kampus interaksi atau komunikasi antara mahasiswi bercadar IAIN Madura dengan dosen IAIN Madura sebagian dosen yang merasa terganggu dengan padanya atribut cadar pada mahasiswi tersebut dan membuat identitas mahasiswi bercadar tersebut sulit dikenali. Sedangkan komunikasi antara mahasiswa IAIN Madura dengan mahasiswi bercadar IAIN Madura sebagian mahasiswa merasa terganggu dengan adanya atribut cadar tersebut yang terkesan lingkungan dan orangorang sekitarnya merasa kotor dan kurang tepat jika pemakaian atribut cadar di pakai di dunia kampus. Mahasiswa bercadar juga sering dibilang sebagai penyusup, dianggap teroris, kurang bisa diterima dengan baik oleh dosen pengajar, dibentak oleh bagian BPD saat PBAK, kurang disukai oleh teman kelas dan sempat pernah diludahi oleh salah satu dosen IAIN Madura.

Sebagian dosen menganggap tidak ada perbedaan antara mengajar mahasiswi yang bercadar dengan mahasiswa pada umumnya, karena yang terpenting baginya ialah transfer knowledge. Ada sebagian dosen yang lebih suka kalau semua mahasiswi memakai cadar karena dari hal tersebut profesionalitas lebih diutamakan dan dapat terhindar dari fitnah. Dan sebagian mahasiswa tidak merasakan perbedaan antara bergaul dengan mahasiswi bercadar dengan mahasiswi yang tidak bercadar, malah mereka merasakan adanya transfer positif dengan alasan karena mereka lebih condong melakukan hal-hal yang baik. Mahasiswi bercadar juga terkesan lebih dihormati dan dihargai oleh kaum laki-laki, dan tidak diganggu saat berjalan sendirian. Teori pada temuan tersebut belum peneliti temukan dan merupakan temuan baru yang peneliti temukan di lapangan.

Berbagai macam problematik yang dialami mahasiswi bercadar IAIN Madura yaitu seperti pandangan masyarakat dan tokoh masyarakat sekitar rumah mereka yang mana ada masyarakat yang mendukung dan ada pula masyarakat yang tidak mendukung terhadap pemakaian atribut cadar tersebut. Ada di sebagian daerah yang tokoh masyarakatnya mendukung dan ada pula di suatu daerah yang tokoh masyarakatnya tidak mendukung. Pemakaian atribut cadar membuat mereka jadi kurang bisa dikenal identitasnya di masyarakat.

Kontroversi tentang wanita bercadar juga semakin kuat dengan seringnya ada pemberitaan melalui dunia maya, televisi, majalah, koran atau semacamnya tentang wanita bercadar yang merupakan istri dari seseorang yang terlibat dalam aksi terorisme. 
Cadar mulai diidentikkan dengan aksi terorisme pada tahun 2000. Hal tersebut membuat sebagian masyarakat beranggapan adanya stigma pada atribut cadar. ${ }^{35}$ Sebagian masyarakat lagi beranggapan bahwa wanita memakai cadar hanya sebagai kedok belaka dan tergolong pada aliran sesat ditambah lagi dengan anggapan bahwa wanita bercadar tidak bisa diajak bersosialisasi atau membatasi sosialisasi dengan sesamanya dan bahkan ada yang beranggapan bahwa wanita bercadar hanya sekadar untuk menutupi kejelekannya. ${ }^{36}$

Terdapat salah satu keluarga dari mahasiswi IAIN Madura yang bercadar sangat tidak mendukung pemakaian atribut cadar padanya sehingga mengharuskan pemakaian cadar dipakai secara diam-diam. Namun ada lagi di daerah lain dengan problem yang tidak didukung orang tua namun akhirnya orang tua tersebut juga bisa sedikit mengikuti penampilan mahasiswi bercadar tersebut. Temuan tersebut merupakan temuan baru yang didapat peneliti karena belum ditemukannya teori yang cocok untuk temuan ini.

Perspektif negatif yang timbul karena adanya atribut cadar pada wanita bercadar tidak dapat dipungkiri lagi. Hal tersebut dianggap mengganggu dan membatasi interaksi atau komunikasi antar makhluk hidup. Komunikasi antara kalangan bercadar dengan kalangan yang tidak bercadar cukup sulit. Masyarakat umumnya bersikap tertutup terhadap kehadiran mereka. Hal tersebut dikarenakan doktrin yang tersebar di masyarakat bahwa wanita bercadar identik dengan aksi terorisme. Perbedaan busana yang dipakainya juga menyebabkan adanya perasaan perbedaan lingkungan bagi masyarakat. ${ }^{37}$ Hambatan yang biasa terjadi dalam komunikasi mahasiswi bercadar ialah seperti intonasi suara tidak terdengar, ekspresi wajah yang tidak mudah ditebak yang mana hal tersebut dikarenakan adanya cadar yang menghalanginya. ${ }^{38}$

Solusi yang dilakukan oleh mahasiswi bercadar saat menghadapi beberapa problem yang terjadi ialah lebih bersabar dan memilih diam, lalu menghadapi semua permasalahan dengan tenang dan berusaha membicarakannya dengan baik-baik. Dua solusi yang bisa dilakukan oleh wanita bercadar dalam menghadapi stigma tentang dirinya yaitu dengan cara intrapersonal (internal pribadi) yaitu dengan mengatur emosi dan bersabar serta tidak begitu memikirkan sikap negatif orang lain dan interpersonal (bersifat eksternal) dengan melakukan pendekatan pada masyarakat yang memberi stigma. ${ }^{39}$

\footnotetext{
${ }^{35}$ Rahman dan Syafiq, Motivasi, Stigma dan Coping Stigma pada Perempuan Bercadar, 104.

${ }^{36}$ Tanra, Persepsi Masyarakat Tentang Perempuan Bercadar, 117.

37 Vito Septian Eka Wiyanto, "Perspektif Masyarakat Terhadap Wanita Bercadar (Studi pada Masyarakat di Kelurahan Segalamider Kota Bandar Lampung)" (Skripsi, Universitas Lampung Bandar Lampung, 2018), 3.

38 Yuni Sara, Komunikasi Sosial Mahasiswi Bercadar Fakultas Dakwahdan Komunikasi UIN Alauddin Makassar, 100.

${ }^{39}$ Alif Fathur Motivasi, Stigma dan Coping Stigma, 109.
} 


\section{Risalatil Falihah}

Fenomena cadar IAIN Madura tidak bertentangan dan sesuai dengan penafsiran pada surah al-Ahzab ayat 59 dan surah al-Nur ayat 31 dalam tafsir al-Azhar. karena seluruh informan mengatakan bahwasanya cadar itu tidak wajib. Hal tersebut sesuai dengan pendapat Hamka yang mengatakan bahwasanya wajah, dan tangan bukan merupakan perhiasan yang harus ditutupi.

Tafsir al-Azhar merupakan kitab Tafsir karya Buya Hamka yang metodenya menggunakan metode tahlîlî. Kitab tafsir tersebut terdiri dari sembilan jilid. Buya Hamka dikatakan sebagai generasi kedua dari dunia ahli tafsir karena dalam penafsirannya terdapat perbedaan yang sangat mencolok dari penafsiran yang lalu yang dilakukan oleh Prof. Mahmud Yunus. ${ }^{40}$ Dalam sejarah yang tercatat Buya Hamka yang paling semangat menyemarakkan gerakan Islam termasuk gerakan penutupan aurat di daerah tempat tinggalnya yaitu di Minangkabau. Penjelasan tersebut juga sudah dijelaskan dalam kitab tafsirnya yaitu pada ayat 59 dari surah al-Ahzab dan ayat 31 dalam surah al-Nur. Kewajiban menutup aurat sudah dijelaskan dalam tafsir kedua ayat tersebut serta tujuannya. Surah al-Ahzab (33) ayat 59 berbunyi;

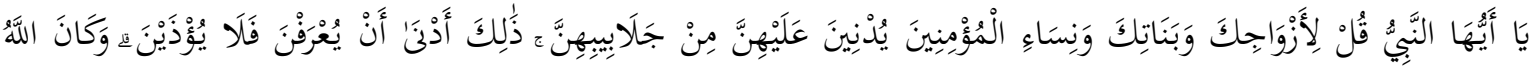
غَفْورًا رَحِيم "

"Hai Nabi, katakanlah kepada isteri-isterimu, anak-anak perempuanmu dan isteriisteri orang mukmin: "Hendaklah mereka mengulurkan jilbabnya ke seluruh tubuh mereka". Yang demikian itu supaya mereka lebih mudah untuk dikenal, karena itu mereka tidak di ganggu. Dan Allah adalah Maha Pengampun lagi Maha Penyayang."

Ayat tersebut turun agar supaya terdapat perbedaan antara wanita muslimah (baik-baik) dengan wanita budak atau pembantu rumah tangga. Dahulu orang belum mempunyai kakus untuk tempat pembuangan hajat, dan jika wanita ingin membuang hajat pada malam hari, ia harus keluar ke tempat yang tersisihkan untuk membuang hajat. Dan disitulah kesemapatan bagi laki-laki jahat untuk menganggu mereka. Karena tidak ada perbedaan antara wanita muslimah (baik-baik) dan wanita budak, maka mereka menyamaratakan semua perempuan yang ada di sana. Mereka mengganggu mereka, namun jika wanita tersebut bersorak-sorak, mereka kabur. Lalu ayat tersebut turun untuk memberikan pembeda antara wanita muslimah (baik-baik) dengan wanita budak. Jadi setelah ayat tersebut turun, terlebih dahulu istri dan putri-putri Nabi yang menggunakan jilbab, lalu kemudian istri-istri dan putri-putri orang mukmin. Setelah wanita muslim memakai jilbab, di saat mereka membuang hajat, laki-laki jahat tidak berani untuk menghampirinya. Namun jika laki-laki jahat tersebut melihat wanita yang tidak memakai jilbab atau budak, maka mereka mengerumuninya. ${ }^{42}$

\footnotetext{
${ }^{40}$ Avif Alviyah, Metode Penafsiran Buya Hamka dalam Tafsir al-Azhar, 25.

${ }^{41}$ Al-Qur'an, al-Ahzab (33): 59

${ }^{42}$ Hamka, Tafsir al-Azhar, Juz XVII, 93.
} 
Dalam al-Qur'an tidak disebutkan model pakaian yang baik dipakai oleh wanita. Al-Qur'an hanya menunjukkan agar wanita berpakaian sopan, yang tidak memperlihatkan bentuk tubuhnya. Mungkin akan lebih baik apabila yang menjadi designer model pakaian wanita ialah seseorang yang beriman kepada Allah dan paham tentang kriteria pakaian menurut syariat Islam. ${ }^{43}$

Pada tahun 1926, wanita di Tanjung Pura dan Pangkalan sudah memakai jilbab. Mereka memakai kain sarung yang ditutupkan ke seluruh badan sehingga hanya kelihatan separuh wajah saja bahkan hanya kelihatan mata saja. Sedangkan di Makassar pada tahun 1931, wanita-wanita yang sebagian bekerja sebagai buruh kopi di gudanggudang di pelabuhan Makasar sudah memakai jilbab. Di Bhima, pada tahun 1956 wanita Bhima sudah berselimut kain sarung ketika hendak keluar rumah. Pada tahun 1967 wanita di Gorontalo sudah memakai jilbab di luar bajunya meskipun di dalamnya mereka memakai rok moden. Wanita dalam gerakan Aisyiyah di Tanah Jawa, atas anjuran H.A Dahlan selain memakai khimâr (selendang) yang dililitkan ke dada (agar tidak kelihatan), juga difungsikan untuk menutup kepala. Sedangkan gerakan Aisyiyah di Yogyakarta pada tahun 1924 sudah memakai khimâr penutup kepala dan dada. Di samping itu pula gerakan Aisyiyah juga memakai jilbab di luarnya. ${ }^{44}$

Buya Hamka menyebutkan dalam kitab tafsirnya bahwa Jilbab merupakan simbol kesopanan kaum wanita. Semakin sopan wanita tersebut, semakin sopan pula pakaian yang dipakainya. Semakin sopan seorang wanita, semakin besar pula jilbab yang dipakainya, bahkan bisa juga dengan ditambah cadar di wajahnya. Surah al-Nur (24) ayat 31 berbunyi;

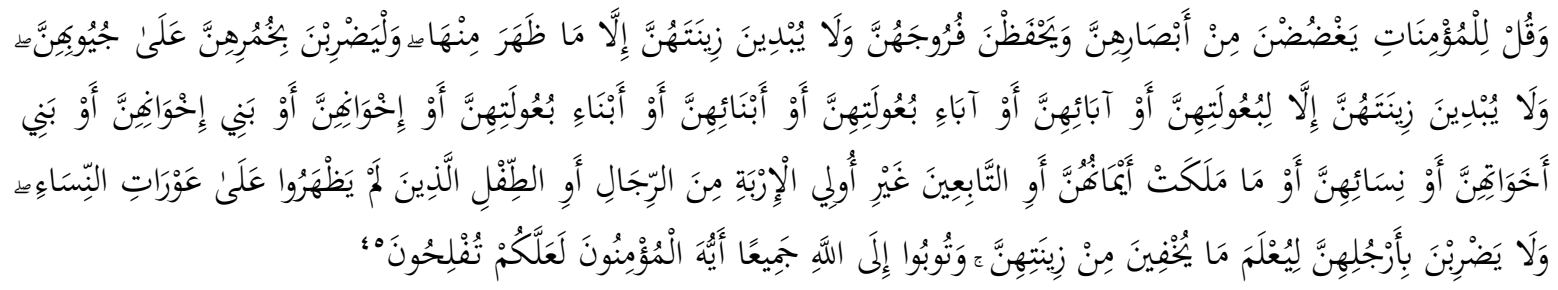

“Katakanlah kepada wanita yang beriman: "Hendaklah mereka menahan pandangannya, dan kemaluannya, dan janganlah mereka menampakkan perhiasannya, kecuali yang (biasa) nampak dari padanya. Dan hendaklah mereka menutupkan kain kudung kedadanya, dan janganlah menampakkan perhiasannya kecuali kepada suami mereka, atau ayah mereka, atau ayah suami mereka, atau putera-putera mereka, atau putera-putera suami mereka, atau saudara-saudara lakilaki mereka, atau putera-putera saudara lelaki mereka, atau putera-putera saudara perempuan mereka, atau wanita-wanita islam, atau budak-budak yang mereka miliki, atau pelayan-pelayan laki-laki yang tidak mempunyai keinginan (terhadap

\footnotetext{
${ }^{43}$ Ibid, 98.

${ }^{44}$ Ibid., 97.

${ }^{45}$ Al-Qur'an, al-Nur (24):31.
} 


\section{Risalatil Falihah}

wanita) atau anak-anak yang belum mengerti tentang aurat wanita. Dan janganlah mereka memukulkan kakinyua agar diketahui perhiasan yang mereka sembunyikan. Dan bertaubatlah kamu sekalian kepada Allah, hai orang-orang yang beriman supaya kamu beruntung."

Sebagai makhluk sosial, antara laki-laki dan perempuan pasti saling membutuhkan. Laki-laki membutuhkan perempuan dan perempuan membutuhkan lakilaki. Sudah mejadi fitrah bagi setiap manusia, antara laki-laki dan perempuan memiliki saling ketertarikan. Oleh karenanya, dalam ayat sebelumnya, yakni ayat 30, al-Qur'an memerintahkan laki-laki untuk menundukkan pandangannya agar tidak terjadi hal-hal yang tidak diinginkan. Untuk tetap menjaga keseimbangan serta memberikan keadilan antara laki-laki dan perempuan, dalam ayat 31, al-Qur'an memerintahkan kepada kaum wanita untuk menutup auratnya. Ayat tersebut berisi peringatan kepada kaum wanita untuk menutup rapat uaratnya, mengulurkan kain kerudung di kepalanya hingga menutupi dadanya, kecuali yang sudah biasa tampak atau perhiasan yang nyata daripada mereka yaitu cincin di tangan, wajah dan tangan. Hamka juga mengatakan dalam kitab tafsirnya agar para wanita benar-benar menutup auratnya dengan sempurna tanpa memperlihatkan bentuk tubuh nya, terutama bagian dada. Bagian tersebut masuk dalam pembahasan "juyub" atau "lubang" yang tidak boleh diperlihatkan ${ }^{46}$

Dapat disimpulkan dari penafsiran tersebut bahwa cadar menurut Hamka bukan merupakan kewajiban karena wajah serta tangan merupakan perhiasan wanita yang biasa tampak atau diperbolehkan tampak dikarenakan Hamka menganggap terlalu sulit jika wajah dan tangan harus juga ditutupi. Meskipun demikian Hamka tidak melarang jika wajah dan tangan tersebut ingin ditutupi. Hal tersebut dapat dilihat dari beberapa pendapat tokoh yang Hamka kutip dan juga kisah perjalanan Hamka ke beberapa daerah di Nusantara dengan kisah wanita yang mengaplikasikan jilbab yang dipakainya untuk menutupi seluruh tubuhnya juga menutupi wajahnya sehingga hanya terlihat mata saja.

Tafsir tersebut sesuai dengan fenomena yang terjadi di IAIN Madura karena keseluruhan informan termasuk keseluruhan mahasiswi IAIN Madura yang memakai cadar mengakui bahwasanya cadar tidak wajib dikenakan oleh wanita muslimah. Pemakaian cadar hanya dilakukan untuk menjaga diri dan memperbaiki diri menjadi lebih baik lagi. Pendapat ketidak wajiban cadar tersebut dibuktikan oleh salah satu mahasisiwi bercadar di IAIN Madura yang saat ini sudah melepas cadar. Hal tersebut dilakukan bukan untuk menghina atau mempermainkan agama, melainkan karena beberapa tuntutan seperti terpilih menjadi ketua IPPNU Tlanakan dan karena tidak didukung oleh orang tuanya. Hal tersebut bukan suatu kesalahan karena bertanggung jawab terhadap jabatan ketuanya dan mematuhi perintah orang tua hukumnya wajib, sedangkan memakai cadar hukumnya tidak wajib. Oleh karenanya tidak salah jika harus melepas hal yang tidak wajib untuk memenuhi kewajibannya.

${ }^{46}$ Hamka, tafsir al-Azhar, Juz XVII, 179. 
Ketidak wajiban cadar juga selalu diperbincangkan di kalangan mahasiswa ataupun dosen yang kurang setuju terhadap pemakaian artibut cadar. Hal tersebut dikarenakan seperti ada gangguan atau seperti ada batasan yang sangat berbeda dengan adanya cadar tersebut. Dari cadar juga sebagian orang beranggapan bahwasanya hal tersebut seperti suatu hujatan atau anggapan bahwa orang-orang di sekitarnya seperti kotor sehingga mahasiswi tersebut memakai cadar. Selain itu juga pakaian yang dipakai Mahasiswi Bercadar di IAIN Madura sudah memenuhi terhadap beberapa kriteria atau ketentuan berpakaian bagi seorang wanita yang tertulis dalam tafsir al-Azhar.

\section{PENUTUP}

Konsep cadar mahasiswi IAIN Madura ialah cadar merupakan sebuah kain yang berfungsi untuk menutup wajah sehingga hanya terlihat mata saja. Latar belakang keluarga mahasiswi IAIN Madura yang bercadar ialah tidak semuanya berasal dari keluarga yang berdarah biru ataupun keluarga ulama. Motivasi mahasiswi IAIN Madura memakai cadar ialah untuk bisa menjaga diri dari hal-hal yang buruk dan agar bisa memeperbaiki diri menjadi lebih baik lagi dan mengubur masalalu yang buruk serta untuk menghindari fitnah. Kelebihan dari cadar ialah dapat menjaga dirinya dari hal-hal buruk, memberikan rasa aman, dan merasa lebih dekat dengan Allah. Pemakaian cadar dapat memberikan rasa aman dan tenang terhadap pemakainya.

Problematika yang dialami oleh mahasiswi bercadar di IAIN Madura ialah kehadirannya tidak bisa diterima dengan baik oleh sebagian golongan, seperti sebagian keluarga, masyarakat, dosen dan mahasiswa karena adanya sangkaan teroris, Islam garis keras dan radikal yang selalu dituduhkan pada mahasiswi yang bercadar. Mahasiswi bercadar IAIN Madura terkadang diperlakukan tidak wajar oleh orang sekitar seperti diludahi. Atribut cadar yang dipakai dianggapp terlalu berlebihan. Pihak yang tidak menerima cadar menganggap kampus bukan dunia tidak aman, jadi tidak perlu memakai cadar. Pemakaian cadar juga dapat membatasi interaksi dan menyulitkan identitasnya untuk diketahui. Terdapat salah satu mahasiswi IAIN Madura yang melapas cadar yang pernah dipakainya dikarenakan lebih mengedepankan hal yang wajib baginya yaitu mematuhi perintah orangtua dan bertanggung jawab sebagai ketua IPPNU Tlanakan. Solusi yang dilakukan oleh wanita bercadar atas problem yang dihadapinya dengan cara dima saja dan bersabar dan mencoba membicarakannya dengan baik-baik.

Fenomena cadar IAIN Madura tidak bertentangan atau sesuai dengan penafsiran pada surah al-Ahzab ayat 59 dan surah al-Nur ayat 31 dalam tafsir al-Azhar karena seluruh informan mengatakan bahwasanya cadar itu tidak wajib. Hal tersebut sesuai dengan pendapat Hamka yang mengatakan bahwasanya wajah, dan tangan bukan merupakan perhiasan yang harus ditutupi. Kriteria pakaian yang dipakai oleh mahasiswi bercadar di IAIN Madura 97\% sesuai dengan makna yang tersirat dalam tafsir al-Azhar yaitu dengan benar-benar menutup seluruh tubuh dan juga dada tanpa memperlihatkan bentuk tubuhnya. 


\section{DAFTAR PUSTAKA}

Alviyah, Avif. Metode Penafsiran Buya Hamka dalam Tafsir al-Azhar. Ilmu Ushuluddin. Vol.15. No. 1. Januari 2016.

As-Sya'rawi, Mutawalli. Fikih Perempuan (Muslimah) Busana dan Perhiasan, Penghormatan atas Perempuan, Sampai Wanita Karier. Jakarta: Amzah. 2003.

Az-Zuhaili, Wahbah. al-Tafsir al-Munîr fi al-'Aqîdah wa asy-Syarî'ah wa al-Manhaj Jilid 11. Beirut: Dâr al-Fikr. 2011.

Hamid, Idham. Tradisi Ma'baca Yasin di Makam Annangguru Maddappungan Santri Pondok Pesantren Salafiyah Parappe Kec. Campalagian Kab. Polewali Mandar. Skripsi. Universitas Islam Alamuddin. Makassar. 1994.

Hamka. Tafsir al-Azhar Jakarta: PT. Pustaka Panjimas. 1986.

Khotimah, Romadhoni Kusnul. Komunikasi Perempuan Bercadar di Komunitas Kahf Surabaya. Skripsi. Universitas Islam Negeri Sunan Ampel, Surabaya. 2018.

Mansur, M. @ al., Metodologi Penelitian Living Qur'an dan Hadis. Yogyakarta: Teras. 2007.

Marâghī, Ahmad Mushthafa. Tafsir al-Marâghī. Beirut: Dâr al-Fikr. 2010.

Mutabahhar, Jalâl al-Dīn Muhammad bin Ahmad al-Mahallī Syaikh dan Jalâl alDīn 'Abdu ar-Rahman bin Abī Bakrin as-Suyûthī. Tafsīr al-Qur'an al-'Azhīm. Surabaya: Dâr al-Jawâhir. t.t.

Rahman, Alif Fathur dan Muhammad Syafiq, Motivasi, Stigma dan Coping Stigma pada Perempuan Bercadar. Jurnal Psikologi Teori dan Terapan. Vol. 7. No. 2. Februari, 2017.

Rusmiyati, Mei. Perilaku Komunitas Mahasiswi S1 yang Bercadar di IAIN Purwokerto. Skripsi. IAIN Purwokerto, Purwokerto. 2017.

Sara, Yuni. Komunikasi Sosial Mahasiswi Bercadar Fakultas Dakwahdan Komunikasi UIN Alauddin Makassar. Skripsi. Universitas Islam Negeri Alauddin Makassar. 2017.

Setyarini, Maya. Prasangka Sosial Civitas Akademika Terhadap Wanita Bercadar di Lingkungan Perguruan Tinggi Islam. Skripsi. Universitas Muhammadiyah, Surakarta. 2018.

Susanti, Ade. Gambaran Persahabatan dan Penysuaian Diri pada Mahasiswi UIN Jakarta yang Mengenakan Cadar. Skripsi. Universitas Islam Negeri Syarif Hidayatullah, Jakarta. 2008.

Tanra, Indra. Persepsi Masyarakat Tentang Perempuan Bercadar. Jurnal Equilibrium. Vol III. No. 1. Mei 2015.

Wiyanto, Vito Septian Eka. Perspektif Masyarakat Terhadap Wanita Bercadar (Studi pada Masyarakat di Kelurahan Segalamider Kota Bandar Lampung). Skripsi. Universitas Lampung Bandar Lampung. 2018.

Y, Khairunnisa. Komunikasi Nonverbal Muslimah Bercadar di Kalangan Mahasiswi UIN ar-Raniry. Skripsi. Universitas Islam Negeri ar-Raniry, Banda Aceh. 2017. 